\title{
Developing the Metodology to Form Integrated Reporting of Agroholdings in the Russian Federation
}

\author{
N. N. Balashova ${ }^{1}$, E. Šilerová ${ }^{2}$ V. A. Melikhov ${ }^{1}$ \\ ${ }^{1}$ Volgograd State Agrarian University, Volgograd, Russia \\ ${ }^{2}$ Faculty of Economics and Management, Czech University of Life Science Prague, Czech Republic
}

\begin{abstract}
The article represents the efficient methodological principles on preparing the integrated reporting, as well as the scheme of the agroholding coherently integrated registration system based on the analysis of the concept and methodology in the field of the integrated reporting; it specifies "growth points" of the methodology development and best practical applications of the concept of uniform reporting on a global scale. The authors propose the developed by them "road map" on the organization process forming the integrated reports, and define the guidelines on improving the process of preparing and quality of the integrated reporting for the medium-term period.
\end{abstract}

\section{Keywords:}

Methodology of integrated reporting; uniform accounting system; agro-industrial holdings; organization of integrated accounting; road map; guidelines on methodology development.

Balashova, N. N., Šilerová and E., Melikhov, V. A. (2015) "Developing the metodology to form integrated reporting of agroholdings in the Russian Federation", AGRIS on-line Papers in Economics and Informatics, Vol. 7, No. 4, pp. 19 - 29, ISSN 1804-1930.

\section{Introduction}

The current state of modern agriculture in the Russian Federation requires intensive development both of agro-industrial production (technologies, selection) and improvement of control system for the agricultural enterprises to solve the tasks of import substitution, economic security of the country in the period of applying sanctions against Russia and retaliatory food embargo (Medvedev, Putin et al., 2015).

Large diversified integrated agroindustrial holdings are of special importance in this process. We believe that the reporting of such entities as an element of effective management should be of fundamentally different (higher) level and different quality (Ovchinnikov et al., 2014). In 2012 - 2015 in the world and Russia the regulations for corporate reporting changed significantly: the G4 version of the Reporting Guide in the field of sustainable development (GRI) was published; the International standard for the integrated reporting was developed and came into effect; the National concept of development of public non-financial reporting in the Russian Federation and new version of the Corporate
Management Code are expected to be published (Pavlova et al., 2014).

In our researches, we developed the concept of the formation of coherently integrated reporting for agricultural holdings, revealed the prerequisites for developing the author concept, as well as specified the opportunities for integrated reporting application in accounting practice of agricultural holdings (Melikhov, et al., 2014). Besides there were represented the fundamental principles of coherence between accounting and disclosure of financial and non-financial information, and basic aspects and parameters of the concept (Balashova et al., 2014).

At the present stage, the task is to develop methodology to form the integrated reporting for large integrated structures, and in particular, to elaborate the methods and ways of obtaining information for reports, to adopt the strategy in order to organize a system of single, unified accounting. There are various works and issues relating to the theoretical methodology elements, e.g. an International Standard for Integrated Reporting, etc. (Conceptual framework for financial reporting, 2013; Consultant project 
of the international structure integrated reporting, 2012; International standard on the integrated reporting, 2014), but in the practical methodology, which is focused on solving practical problems, and aimed at implementing the concept of integrated reporting, there is a shortage of programs (algorithms), tools (techniques and methods) correlating different accounting systems in a single system and forming a unified reporting based on accounting data that are generated in the system.

Having analyzed best international practices in the preparing integrated reports, we may note that not all the methods are qualitative and effective. Research activities should be focused on the methodological, organizational and technical tasks, in order to find the principles of achieving the purpose to form, present and verify qualitative relevant and pertinent unified reporting.

\section{Research purposes and aims}

Conducting our research, we aim to develop and propose to use tool that helps to develop the methodology of formation and verification of integrated reporting for agricultural holdings in Russia.

To achieve the purpose we have set the following objectives:

1. To analyze and summarize globally all the methodological and procedural frameworks on preparing the integrated reports on the basis of functioning of the unified or separate accounting systems;

2. To propose a structure for the system of coherently integrated accounting;

3. To determine the "points of growth" of methodology development for integrated reporting and the practices of applying the concept of integrated reporting;

4. To develop and recommend a road map of the process of preparing the integrated reporting for agricultural holdings (to determine the logical structure, procedures, objects, forms, means, methods, results of the accounting and control process and the timing to implement the project: phases, stages, steps).

5. To recommend actions to develop the methodology organizing the system of preparing and forming the process of integrated reporting for the medium-term period (3 years): the structure of the report, accounting policies, technical regulations, chart of accounts, workflow, technique for information correlation, a formal system to collect data, registers, data verification.

\section{Materials and methods}

The key issue to implement effectively integrated reporting project is a qualitative justification of a common methodology to form a single, unified reporting (principles, norms for sustainable functioning of the accounting system of the agricultural holding, which help to obtain the required data format).

We use a conceptual approach as the main research method; to implement it we analyze the phenomena and processes associated with the process of preparing integrated reports, as well as reveal a complex of their elements and relationship between the constitutive elements of the integrated reporting concept. It is important to introduce the character and the limits of the interactions and to determine the processes of convergence of data from different accounting systems. The method is based on observation, analysis and synthesis of theoretical opinions on the research topic.

The second approach, constituting a single complex, is a formal one that promotes establishing strong connection between the elements of coherently integrated accounting through formalized algorithm organizing the system. A formal methodology for the preparation of integrated reporting is closely related to the analysis of research methods from the point of view of logical structure and formalized approaches to the construction of the theoretical knowledge, its truth and reasoned argument.

\section{Methodology of integrated reporting}

In the research process, we conducted a review of all legal documents on integrated reporting in the global and national scale and presented the author generalization of the methodological principles to prepare the first set of integrated reporting (Table1). While implementing, the project of integrated reporting should be consistent with the action plan based on the International Integrated Reporting Framework (IIRF) methodology, the methodological recommendations to be practically applied in a more effective way. The methodological aspects of organizing the system of integrated reporting for agricultural holdings have their own specifics, as different industries have different business models, business strategies and the mechanisms of value creation. 


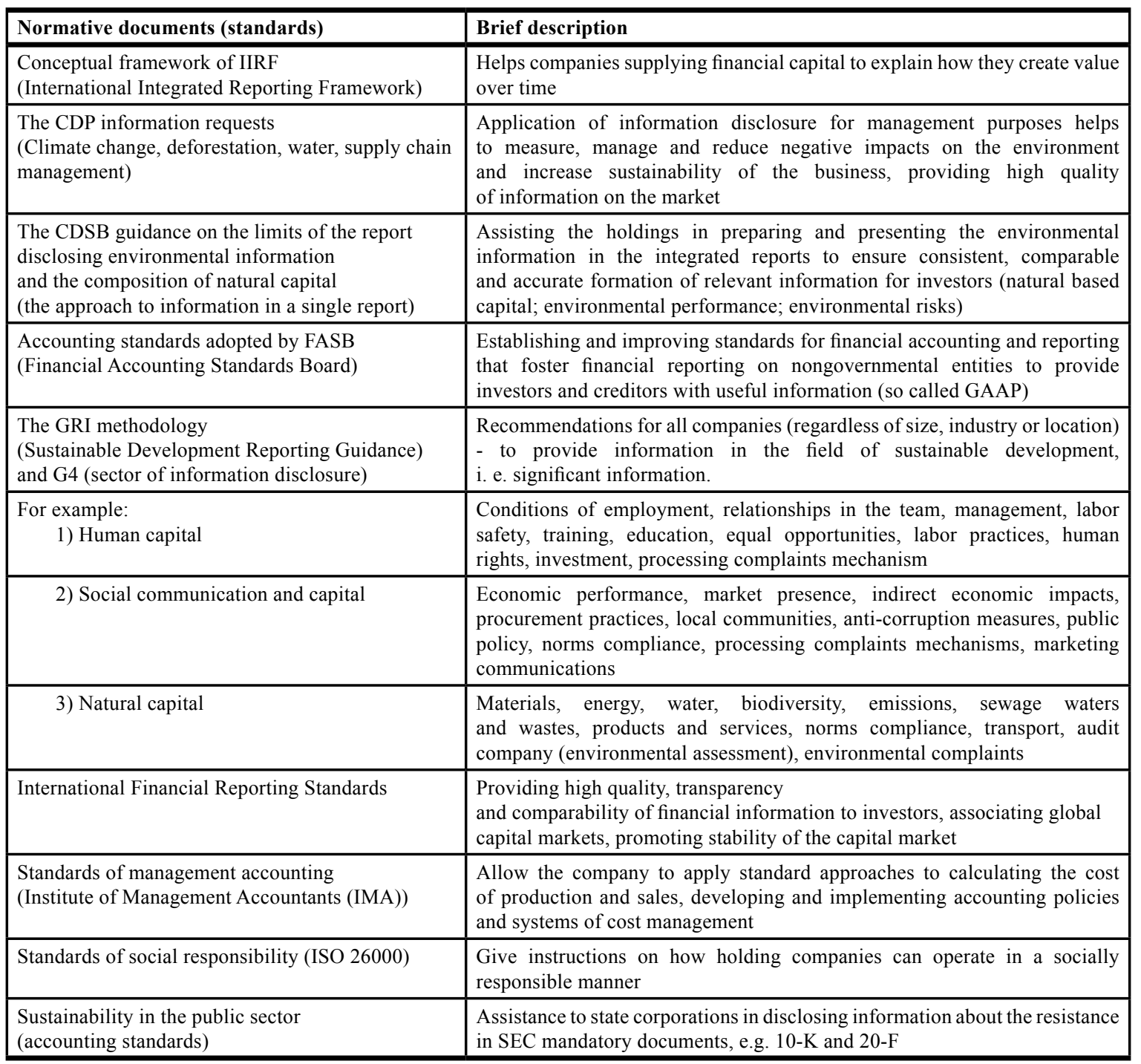

Source: Brožová (2009), Higgins (1952), International standard on the integrated reporting, Medvedev (2015)

Table 1: Methodological principles to form the first set of integrated reporting for holding company.

\section{Results and discussion}

The concept of integrated reporting has been occupying the first pages of the world professional accounting journals. Integrated reporting (IR) brings together financial and non-financial information and reflects the organization's ability to create and sustain its value in the short, medium and long term (Cheng et al., 2013, Dhaliwal et al., 2011, Eccles et al., 2011). Jim Singh, CFO of Nestle, said that "...if you need to improve the credibility of your company in the long run, then integrated reporting is your choice " (Integrated reporting Discussion Paper, 2011).

Integrated reporting was firmly on the agenda at the World Congress of Accountants 2014 in Rome. All panelists described the benefits their organizations had experienced through integrated thinking and reporting.

For example, Mr. Holland spoke enthusiastically about Integrated reporting being a bridge to investors for Gold Fields, and its importance in attracting a wider investor base (Tomorrow's Business Success, 2014). Neil Stevenson, Managing Director of Global Implementation at the IIRC has written a blog about the Congress and how it paves the way to adoption of IR (Stevenson et al., 2014).

These illustrate a shift in outlook in business towards a wider concept of value creation - a theme echoed by a number of speakers. They also reflect the reality of today's business, as summarized by IIRC CEO, Paul Druckman, who said that "speed and interconnectedness are norms in business 
today". Business needs to respond by planning to achieve long-term outcomes while managing the short term (Druckman et al., 2014).

Integrate: Doing Business in the 21st Century, written by Professor Mervyn King, Chairman, IIRC, and Leigh Roberts, South African Institute of Chartered Accountants, sets out the new corporate tools that businesses should be using. As described by the authors, Integrate "is about why doing business in the 21 st Century is different and the challenges and opportunities this presents to companies. It scrutinizes the contents of the existing corporate toolbox and offers suggestions for new tools". Integrate brings to life the four corporate tools that businesses should be using in the 21 st century: stakeholder relationships, corporate governance, integrated thinking and the integrated report (King et al., 2014).

George Serafeim, Harvard Business School, in the paper shows that investor activism on environmental or social issues or a large number of concerns about a firm's environmental or social impact leads a firm to practice more IR and that this investor or crisis - induced IR affects the composition of a firm's investor base. Finally, firms that report more information about the different forms of capital or follow more closely the guiding principles as described in the IR Framework of the IIRC exhibit a more longterm oriented investor base (Ioannou and Serafeim, 2014). It has been shown that these problems can actually be solved by the development of accounting registers, corresponding to the requirements of the existing legislation in the Republic which allow to fully take into account the economic activity of small businesses (peasant (farm) enterprises, limited liability partnerships, co-operatives. (Iacondini, A. at all.) The issue of a methodology of reporting also addresses Bayboltaeva at all., Brožová and Iacondini at all.

Koichi Kaneda, Senior Director Pharmaceutical Company, discusses how the company got involved in Integrated Reporting, and some of the hurdles they have passed on way. Diana McEwan, Corporate Communications Manager Stockland, discusses how IR can bring value creation to life (IR Yearbook, 2014).

Sabina Ratti, Sustainability Senior Vice President at energy firm Eni, explains why, to her, corporate reporting without IR is like trying to understand.

Delivering the 2014 Richard Dimbleby Lecture, Christine Lagarde focused on "the breakneck pattern of integration and interconnectedness that defines our time".

Research led by Professor Gillian Yeo from Nanyang Business School, Singapore, explored the relationship between effective adoption of IR and corporate valuation. Integrated reporting and corporate valuation examined the results of early adoption in South Africa and found that, "In essence, holding other factors constant, if a firm improves in its IR score across time, it is likely to experience an increase in market valuation" (EY's Excellence in Integrated Reporting Awards, 2014).

Financial accounting, even when recognized for its vital importance to records and controls, is not so used as a managing tool. Having set this stage, it becomes important to check the relevance given to costs systems by the small companies, once the lack of its use may cause the companies to be vulnerable to the global competition. (Zamberlan, C. O.; Zamberlan, J.F. 2009)

Thorsten Pinkepank, Director Sustainability Relations at BASF, talks about the report trilemma of materiality, comparability and audience. Reporting companies find themselves in a colorful landscape of codes, frameworks, indicators. Many of these companies - not only SMEs - are concerned and overburdened by this complexity. Many discussions are summed up with one thing most agree on: the need for "alignment" of the different frameworks or approaches, which suggests principles or indicators.

Having analyzed the materials of the International Integrated Reporting Council and the best practices of application of the International standard for integrated reporting we present all significant results in Table 2 .

Accounting system of the holding company is understood here as a combination of types of accounting (financial, managerial, non-financial), correlated with unity of coherent "growth points" that form the basis of the International standard for integrated reporting (capital: human, manufacturing, natural, social, etc.; business strategy; business model; mechanism of value creation) (Melikhov, Perepelkina et al., 2014) (Figure 1).

Presented principles generate relevant and pertinent information for stakeholder groups. During project implementation, it is important to observe the principle of expediency, i.e. the expenditures for the project should not exceed the effect of the system operation and formation of the reports 


\begin{tabular}{|c|c|c|}
\hline Growth point & Year & An example of the application practice \\
\hline IIRC Pilot Programme launches & October 2011 & \\
\hline \multirow[t]{3}{*}{ Microsoft's Bob Laux: CFOs should care about IR } & December 2011 & \\
\hline & January 2012 & Indra Annual Report 2011 \\
\hline & March 2012 & ARM Annual Report 2011 \\
\hline Regional IR Americas meeting & August 2012 & \\
\hline \multirow[t]{2}{*}{ Yearbook released } & September 2012 & Launch of Emerging IR Database \\
\hline & October 2012 & Gold Fields Annual Review 2012 \\
\hline Research shows positive impact of IR & November 2012 & \\
\hline Investor Network gives backing for IR & December 2012 & National Australia Bank Annual Review 2012 \\
\hline FREUND's planned approach to IR & January 2013 & Stockland Annual Review 2012 \\
\hline \multirow{2}{*}{$\begin{array}{l}\text { - Why IR matters to US company Clorox } \\
\text { - DBS Bank: IR from buy-in to benefits }\end{array}$} & May 2013 & Transnet Integrated Report 2013 \\
\hline & & \\
\hline Why Telefonica has committed to IR & July 2013 & Investors critique reports of companies moving to IR \\
\hline Third IIRC Pilot Programme Conference & September 2013 & New book offers practical guidance \\
\hline IIRC Pilot Programme 2013 Yearbook & November 2013 & \\
\hline \multirow{6}{*}{ CFO of New Zealand Post backs IR } & \multirow{6}{*}{ December 2013} & Aegon's 2013 Integrated Review \\
\hline & & Entergy Integrated Report 2013 \\
\hline & & Itaú Unibanco Integrated Report 2013 \\
\hline & & Munich Airport's reporting approach \\
\hline & & Strate Integrated Report 2013 \\
\hline & & Novo Nordisk Annual Report 2013 \\
\hline \multirow{3}{*}{$\begin{array}{l}\text { The CEO of CPFL Energia on the importance } \\
\text { of an integrated view }\end{array}$} & \multirow{3}{*}{ January 2014} & The Crown Estate Annual Report and Accounts 2013 \\
\hline & & DBS Annual Report 2013 \\
\hline & & Eskom Integrated Report 2014 \\
\hline EnBW on aligning internal stakeholders & February 2014 & Eni Annual Report 2013 \\
\hline Research: IR and corporate valuation & April 2014 & New Zealand Post Group Annual Review 2014 \\
\hline New research reveals 'what good looks like' & June 2014 & BASF: the trilemma of reporting \\
\hline IR Technology Initiative announced & September 2014 & \\
\hline $\begin{array}{l}\text { The Global Commission on the Economy and } \\
\text { Climate calls for IR }\end{array}$ & November 2014 & \\
\hline Governor of the Bank of England endorses IR & January 2015 & World Congress of Accountants paves way to adoption \\
\hline
\end{tabular}

Source: Bavboltayeva et al. (2015), Dhaliwal et al. (2011), Putin (2015), Serafeim (2014)

Table 2: Growth points for developing the integrated reporting methodology and practices of applying the concept

for the company management and the stakeholders. The effect depends on the quality of managerial decision-making based on the information in the reports.

In this context the roadmap is understood as the phased plan of organizational and methodical actions in order to form a coordinated (coherent) vision of progressive accounting and analytical technologies, new tools and standards for financial, managerial and non-financial accounting, new forms and configurations of reporting, potential stakeholders (interested users), the impacts of implementing the integrated accounting as well as forecast of formation and presentation of new reporting for industrial and agricultural holdings in the Russian Federation. Roadmaps formation, in our opinion, makes it possible to clarify the goals of the holdings in the field of corporate public reporting and to identify the ways of achieving them. To solve the above-defined purpose we set the task to develop and present a roadmap to organize the system of integrated reporting, i.e. to provide clearly (visually and in informative way) step-by-step scenario of development of the system of coherently integrated accounting resulted in the formation of a set of integrated reporting. The action plan is based on modern standards regarding international integrated reporting and best practices of the application of these rules. We consider 


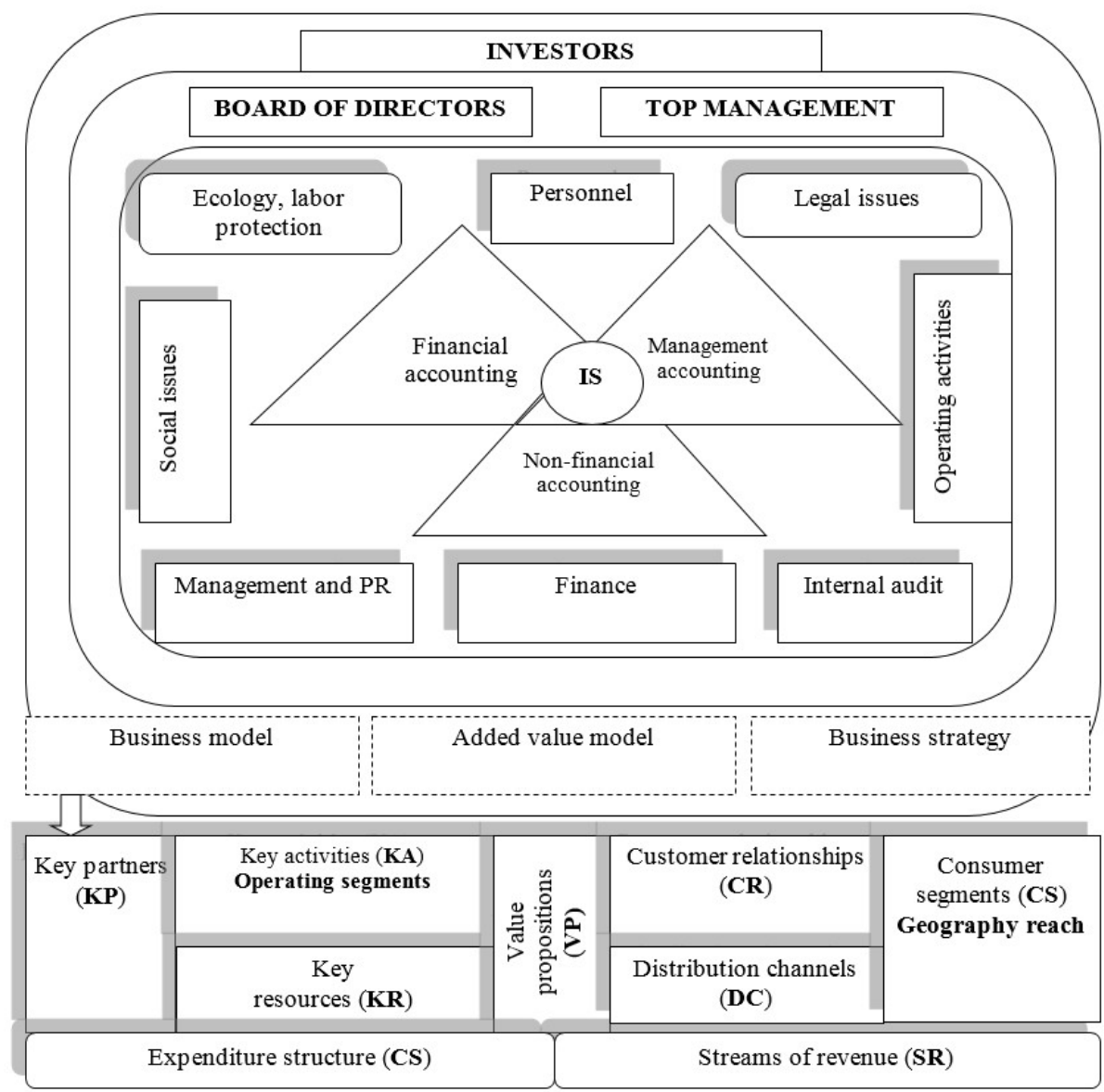

Source: Bavboltayeva et al. (2015), Dhaliwal et al. (2011), Putin (2015), Serafeim (2014)

Table 2: Growth points for developing the integrated reporting methodology and practices of applying the concept.

\begin{tabular}{|c|c|c|c|c|c|}
\hline \multicolumn{6}{|c|}{ AVERAGE DURATION OF THE PROJECT IMPLEMENTATION IS 14 MONTHS } \\
\hline & PHASE 1 & \multicolumn{3}{|c|}{ PHASE 2} & \multirow{3}{*}{$\begin{array}{l}\text { PHASE } 3 \\
\text { Implementation of changes } \\
\text { - Training } \\
\text {-A systematic approach to } \\
\text { collecting information } \\
\text {-Development of procedures } \\
\text { for reporting } \\
\text { implementation of system } \\
\text { changes } \\
\text {-Implementation of changes } \\
\text { in business processes }\end{array}$} \\
\hline & Preliminary stage & Project management & $\begin{array}{l}\text { Components assessment and } \\
\text { decision-making }\end{array}$ & \multirow{2}{*}{$\begin{array}{c}\text { Transition } \\
\text {-Calculation of IIRF } \\
\text { adjustments } \\
\text {-Collecting } \\
\text { information for } \\
\text { disclosures } \\
\text { - Preparing reports on } \\
\text { IR } \\
\text {-Analysis of the results }\end{array}$} & \\
\hline 葛 & $\begin{array}{l}\text { - Assessment of the impact of } \\
\text { the transition to the IIRF on the } \\
\text { financial reporting } \\
\text {-Assessment of the impact on } \\
\text { management processes } \\
\text {-Assessment of resources; } \\
\text {-Adoption of the requirements } \\
\text { of financial reporting external } \\
\text { users; }\end{array}$ & $\begin{array}{l}\text {-Project management } \\
\text { structure; } \\
\text {-The appointment of the } \\
\text { project team, assigning } \\
\text { responsibilities, developing } \\
\text { training strategies; } \\
\text { - Finalization of project } \\
\text { plan and discussion of the } \\
\text { project strategy }\end{array}$ & $\begin{array}{l}\text {-Development of accounting } \\
\text { policies and making decisions on } \\
\text { complex issues, the choice of } \\
\text { alternative accounting options } \\
\text {-Developing reporting templates, } \\
\text { conducting component analysis to } \\
\text { determine adjustments }\end{array}$ & & \\
\hline 䓪 & $\begin{array}{l}\text { - To combine units into a single } \\
\text { structure; approach to the cost } \\
\text { price formation } \\
\text { - Inventory control of balances } \\
\text { - Scheduling organization of } \\
\text { accounting, technical } \\
\text { regulations; } \\
\text { - Calculation of economic } \\
\text { efficiency of integration }\end{array}$ & $\begin{array}{l}\text {-Development and } \\
\text { implementation of a unified } \\
\text { scheme of accounts } \\
\text {-Unification of accounting } \\
\text { records, internal } \\
\text { management reports, } \\
\text { accounting policies } \\
\text {-Centralization and } \\
\text { automation of accounting }\end{array}$ & $\begin{array}{l}\text {-Methodological framework } \\
\text {-Assessment of the impact on the } \\
\text { reporting format, business } \\
\text { processes and systems } \\
\text {-Optimal procedure of workflow; } \\
\text {-Building a system of timely } \\
\text { closing of accounts }\end{array}$ & $\begin{array}{l}\text { - Selecting format of } \\
\text { data acquisition } \\
\text { - Performers } \\
\text { assignment } \\
\text {-Options of structural } \\
\text { units and delegation } \\
\text { of responsibilities }\end{array}$ & $\begin{array}{l}\text { - Development of manuals } \\
\text { and trainings } \\
\text { - Justification of the first } \\
\text { transition to the IIRF } \\
\text { reporting } \\
\text { - Developing internal } \\
\text { methodology of verification } \\
\text { reporting }\end{array}$ \\
\hline 蚠 & $\begin{array}{l}\text { Recommendations on the } \\
\text { content and strategy of the } \\
\text { project reporting, detailed plan } \\
\text { Preliminary analysis of the } \\
\text { impact on reporting } \\
\text {-General structure of the project }\end{array}$ & $\begin{array}{l}\text {-Developing the concept of } \\
\text { report preparing } \\
\text { management } \\
\text {-Coordination of the } \\
\text { project strategy }\end{array}$ & $\begin{array}{l}\text { Accounting policy in accordance with } \\
\text { IIRF } \\
\text {-Determination of the adjustments list; } \\
\text {-Template of reporting in accordance } \\
\text { with IIRF } \\
\text { - Preparing financial reporting in } \\
\text { accordance with IIRF }\end{array}$ & $\begin{array}{l}\text { IIRF - reporting for } \\
1 \text { year } \\
\text {-Assessment of the } \\
\text { impact on business } \\
\text { processes }\end{array}$ & $\begin{array}{l}\text { The mechanism of reporting } \\
\text { preparation in accordance } \\
\text { with IIRF and the process of } \\
\text { its verification }\end{array}$ \\
\hline & 6 weeks & 12 weeks & 16 weeks & 12 weeks & 10 weeks \\
\hline
\end{tabular}

Source: own processing.

Figure 2: Road map" for the process implementation concerning formation of the integrated reporting. 
the following elements of road mapping: a separate integrated report, group of reports (first and second volumes), the accounting policy to form integrated reporting, groups of accounting and analytical, control technologies, timelines, and business units that form reports.

The main objective of the actions for the main stage (phase 2) on organizing coherently integrated accounting is the unification of financial accounting data (based on Russian accounting standards, IFRS, IAS, PISC), according to traditional national standards (e.g. US GAAP), with the management accounting system and the system of accounting other (non-financial) information. This implies developing and adopting a uniform chart of accounts of coherently integrated accounting, optimizing single for all units (components) of the agroholding account registers, reference books of analytics of revenue and expenses, internal management reports. Thus, it is important to develop an accounting policy for the purposes of the coherently integrated accounting, unifying preliminarily principal statements of accounting policies of the component companies (financial accounting, management accounting, and financial accounting). In our opinion, it is the base for correct (performing settings) converting of the national accounting data (or IFRS) in the chart of accounts according to coherently integrated accounting.

To solve the set tasks within phase 2 (road map) we have identified two processes: 1 . Determining report content (volume of recommended procedures; team building; defining the content of the sections and subsections of the report); 2. Text preparing process (development of the report structure; mechanism for the collection of information; procedures for preparing the report).

In order to implement effectively the process of preparing single reports, it is important to observe the following conditions: a) the company operates in the field of sustainable development, thus the management supports the initiatives of sustainable development trend; b) the company is engaged in non-financial accounting; c) the employees understand the strategy and business model and have the opportunity to define essential aspects of the company; d) taking into account key performance indicators (financial and non-financial) at the company level; e) identifying its stakeholders and understanding their interests and needs; f) organizing the formalized system of data collection, including non-financial indicators in all segments.
At the same time the verification of the process, completeness and accuracy of the information, i.e. the fact of internal audit of non-financial data and interaction with stakeholders in the reports preparing process (feedback) is of high priority. Specifying the final stage of organizational activities, it is noteworthy that structures carrying out the verification of the content of coherently integrated report are to be provided with the justification of the first transition to a system of coherently integrated accounting and reporting (submission of the orders on transition to the IIRF (concept of international standard on integrated reporting), accounting policies, annual assessments of assets and liabilities (estimated values), books of transformational amendments, methodological basis of differences.

This article presents the author recommendations to overcome the complexities of reporting preparation and ways to improve the methodology (Figure 3). We believe that the efficiency of the coherently integrated accounting system is directly affected by creating an optimal workflow procedure, forming a timely closing of the accounts, the flexibility of a formalized system of data collection. Progressive system of organizing accounting for agroholding involves the introduction of electronic document management system, which is to raise the level of interaction between the employees, as well as segments of the group. The main aim is to reduce the time of approval, execution of accounting and control procedures, to eliminate delays and loss of primary documents, to comply with the closing reporting deadlines, to prevent instances of fraud or errors that leads to the quality improved and correlation of accounting. The recommended procedures reduce delays in reporting preparing over the medium term and improve cross-functional interaction. 


\begin{tabular}{|c|c|c|c|}
\hline \multicolumn{4}{|c|}{ Recommendations to improve preparing process and quality of integrated reporting for 2016-2018 } \\
\hline $2 L$ & LL & $L_{L}$ & 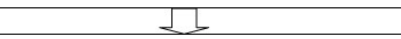 \\
\hline Disclosure of business strategies & Disclosure of business model & Organization of preparing process & Quality and verification of the report \\
\hline$\perp L$ & $\perp L$ & LL & $\perp L$ \\
\hline $\begin{array}{l}\text { Description of activity contexts } \\
\text { (macroeconomics, legal, social) }\end{array}$ & $\begin{array}{l}\text { Text and graphical } \\
\text { description }\end{array}$ & $\begin{array}{l}\text { Organization of a department, service, } \\
\text { office on the formation of IR }\end{array}$ & $\begin{array}{l}\text { Interaction with stakeholders on issues of } \\
\text { accountability and public assurance }\end{array}$ \\
\hline $\begin{array}{c}\text { Conditions of the strategy } \\
\text { implementation }\end{array}$ & $\begin{array}{l}\text { Range and description of } \\
\text { capitals }\end{array}$ & $\begin{array}{l}\text { Organization of the public reporting } \\
\text { system }\end{array}$ & $\begin{array}{l}\text { Organization of internal audit } \\
\text { (Verification Department) of information for }\end{array}$ \\
\hline Detailed explanation of resources & Division of canitals & Organization of quality control for & the integrated reports \\
\hline Detanted expantation on resources & Division or capilals & $\begin{array}{l}\text { reporting formation } \\
\text { (KPI for management) }\end{array}$ & External audit of non-financial information \\
\hline Competitive advantages & Interrelation between the & & \\
\hline Contribution of the fiscal year in & $\begin{array}{l}\text { strategic objectives and } \\
\text { business model }\end{array}$ & $\begin{array}{l}\text { Determination of specific pragmatic } \\
\text { tasks }\end{array}$ & Emplovee motivation \\
\hline achieving the gc & & Taking into account modern trends & Preparation of opening balances \\
\hline Description of key factors for & $\begin{array}{l}\text { Influence of the external } \\
\text { environment }\end{array}$ & (GRI-reports) & and their verification \\
\hline growing /falling markets & $\begin{array}{l}\text { List of products and } \\
\text { services }\end{array}$ & $\begin{array}{c}\text { Analysis of qualification and training of } \\
\text { personnel }\end{array}$ & $\begin{array}{l}\text { Testing procedures (control system, } \\
\text { inventory); Adoption of the regulations }\end{array}$ \\
\hline & Description of the results of & Automation of accounting & of the audit \\
\hline & the model implementation & Report preparation schedule & $\begin{array}{l}\text { Cross-checking procedures, maintenance } \\
\text { of check sheets; Introduction of key }\end{array}$ \\
\hline & $\begin{array}{l}\text { Division into value for the } \\
\text { company and for } \\
\text { stakeholders }\end{array}$ & $\begin{array}{l}\text { The reduction of time resources and } \\
\text { minimization of costs }\end{array}$ & $\begin{array}{l}\text { performance indicators; Audit of } \\
\text { business processes } \\
\text { - Decentralization of accounting }\end{array}$ \\
\hline
\end{tabular}

Source: own processing.

Figure 3: Recommendations to improve preparing process and quality of integrated reporting over the medium term.

\section{Conclusion}

Preparing the integrated reporting is currently one of the most significant trends in the sphere of information disclosure regarding the activities of agricultural holdings. Its emergence and development arose from the gradual change of approaches to the assessment of businesses value and to identifying the factors of their long-term sustainability. Preparing integrated reporting gives companies the advantages, however, its implementation is rather difficult.

The transition to integrated reporting will require significant transformations, efforts and costs from the company through the following processes:

- Organization of internal communication and motivation of employees as part of the reporting process;

- Review of corporate documents and business processes;
- Improvement of the methodology to prepare IR;

- Ensuring the functioning of formalized system of information collection and improving the risk management system.

Preparing integrated reporting the holdings obtain a number of benefits, including developing clearer understanding of business model and ensuring the effectiveness of business processes, as well as increasing the confidence of investors and other stakeholders, strengthening relations with them.

\section{Acknowledgements}

The knowledge and data presented in the paper were obtained as a result of the Grant No. 20151053 of the Internal Grant Agency titled "Development and using information and communication technologies in rural areas".

Corresponding author:

Natalia Nikolaevna Balashova, doctor of economics, professor,

Department of Accounting and Audit, Faculty of Economics

Volgograd State Agricultural University, Russia

E-mail: balashova_nat@mail.ru 
Ing. Edita Šilerová, Ph.D.

Department of Information Technologies, Faculty of Economics and Management

Czech University of Life Sciences Prague, Kamýcká 129, Prague 6 - Suchdol, 165 00, Czech Republic

E-mail: silerova@pef.czu.cz

Viktor Alekseevitch Melikhov Ph.D, associate professor,

Department of Accounting and Audit, Faculty of Economics

Volgograd State Agricultural University, Russia

E-mail:Melikhov707@yandex.ru

\section{References}

[1] Balashova, N. N. Organizational and methodical approaches to the development of the accounting policy for formation of coherent and integrated report of the agro-industrial holdings. Business. Education. Right. Bulletin of the Volgograd institute of business, 2014, Vol. 2, No. 27, p. 99-104. ISSN 1990-536X.

[2] Balashova, N. N., Melikhov, V. A. Conceptual approaches to the disclosure of information on the cost formation at the agro-industrial holdings. Vestnik of Astrakhan state technical university. Series: Economics. 2014, Vol. 3, p. 84-95. ISSN 2224-9761.

[3] Bayboltaeva, N. A ., Makulova, A. T., Abaeva, K., Alibekova, B. A., Bolysbayeva, A. Problems of development of accounting on peasant (Farm) enterprises in Republic of Kazakhstan. Asian Social Science. 2015, Vol. 14, p. 211-218. ISSN 19112017.

[4] Brožová, I. Economic profit of organic farmers in the Czech Republic. Agricultural Economics. 2009, Vol. 56, p. 243-248. ISSN 19112017.

[5] Cheng, B., Ioannou, I., Serafeim. G. 2013. Corporate Social Responsibility and Access to Finance. Strategic Management Journal. 2013, Vol. 35, No. 1, p. 1-23. E-ISSN 1097-0266.

[6] Conceptual framework for financial reporting [Online]. Available: http://finotchet.ru/standard. html?id=65. [Accessed: 20 July 2015].

[7] Consultant project of the international structure. [Online]. Available: IR// www. ir.org.ru/ attachments/article/13/23.11.12 - Consultation Draft of the International Framework-Russian. Pdf. [Accessed: 8 December 2013].

[8] Dhaliwal, D., Li, O. Z., Tsang, A., Yang, Y. G. Voluntary Nonfinancial Disclosure and the Cost of Equity Capital: The Initiation of Corporate Social Responsibility Reporting. The Accounting Review. 2011, Vol. 1, p. 59-100. ISSN 0001-4826.

[9] Druckman, P. Integrated reporting - Gaining global momentum. [Online] Available: https://www. ey.com/ZA/en/Issues/EY-integrated-reporting-hot-topics-paul-druckman [Accessed: 15 Jan 2014].

[10] Eccles, R., Krzus, M. One Report: Integrated Reporting for a Sustainable Strategy. New York: John Wiley and Sons, Inc. 2010, p. 256. ISBN 978-0-470-58751-5

[11] EY's Excellence in Integrated Reporting Awards 2014 [Online]. Available:// www.ey.com/ Publication/vwLUAssets/EY-Excellence-In-Integrated-Reporting-2014/\$FILE/EY -Excellence-InIntegrated-Reporting-2014.pdf [Accessed: 12 March 2015]

[12] Higgins, H. A. Respousibility Accounting. The Arthur Andersen Chronicle. Chicago. April. 1952

[13] Horská, E., Szafrańska, M., Matysik-Pejas, M. Knowledge and financial skills as the factors determining the financial exclusion process of rural dwellers in Poland. 2013, Agricultural Economics, vol.59, pp. 29-37. ISSN 1805-9295.

[14] Integrated reporting. [Online]. Available: http://integratedreporting.org/2014/08/26/the-trilemmaof-reporting/ [Accessed: 23 Sept. 2015]. 
[15] International standard of financial report (IAS) 8 "Accounting policy, changes in the accounting assessments and failures". [Online]. Available at: http://www.acca.com. [Accessed: 28. Aug. 2015].

[16] International standard on the integrated reporting. [Online]. Available at: http://www.pwc.ru// International Integrated Reporting Framework [Accessed: 8. April 2014].

[17] Ioannou, I., Serafeim, G. The Impact of Corporate Social Responsibility on Investment Recommendations. Harvard Business School Working Paper, 2014. No. 1507874.

[18] Iacondini, A., Mencherini, U., Passarini, F., Vassura, I., Fanelli, A., Cibotti, P. Feasibility of Industrial Symbiosis in Italy as an Opportunity for Economic Development: Critical Success Factor Analysis, Impact and Constrains of the Specific Italian Regulations. 2015, Vol. 6, p. 864-874. ISSN 1877-2641.

[19] King, M., Roberts, L. Integrate: Doing Business in the $21^{\text {st }}$ Century [Online] Available: http://www. mervynking.co.za/pages/publications.htm [Accessed: 15 April 2014].

[20] The Landscape map [Online]. Available: http://corporatereportingdialogue.com/landscape-map (Accessed: 10 May 2015);

[21] Medvedev, D. A. Russia could become one of the leading agricultural countries [Online] Available: http://importozamechenie.ru/medvedev-rossiya-mozhet-vojti-v-chislo-vedushhix-agrarnyx-stran/ [Accessed: 8 Febr. 2015].

[22] Melikhov, V. A. Concept and technology of formation of coherent and integrated reporting of the agro-industrial holdings. Volgograd, IPK "Niva", 2014. 132 p.

[23] Melikhov, V. A. Evaluation of the prospects of submitting coherent and integrated report and disclosure of non-financial information of the agro-industrial holding. Theory and practice of social development, 2014, no. 9, pp. 122-125.

[24] Melikhov, V. A., Pavlova. L. N. Perspectives of formation of international integrated report at the agricultural and processing enterprises of the agro-industrial holding. Proceedings of nizhnevolzskiy agrouniversity complex: science and higher vocational education, 2014. Vol. 1, No. 33, p. 243-248. ISSN 2071-9485.

[25] Ovchinnikov, A. S., Tseplyaev, A. N., Balashova, N. N., Šilerová, E., Melikhov, V. A. Monitoring of Integrated Accounts Rendering and Non-Financial Information Disclosure to Agricultural Holdings (on the Basis of the Volgograd Region), Agris on-line Papers in Economics and Informatics. 2014, Vol. 6, No 4, p. 89-100. ISSN 1804-1930.

[26] Perepelkina, E. F. Unified system of management account and IFRS as a instrument of disclosure of data on operating segments of the agro-industrial holding. Proceedings of nizhnevolzskiy agrouniversity complex: science and higher vocational education. 2014, Vol.1, No. 33, p. 253-259. ISSN 2071-9485.

[27] Putin, V. V. Message from the President to the Federal Assembly// Bulletin of the Russian nation. 2015, Vol. 1-1, No. 39. p. 8-16.

[28] Realizing the benefits: The impact of Integrated Reporting [Online]. Available: www.theiirc.org [Accessed:15.06.2015].

[29] Serafeim, G. Integrated Reporting and Investor Clientele//Harvard Business School Working Paper. 2014, No. 12-072.

[30] Stevenson, N. Key foundations for high-quality reporting: Good practices of monitoring and enforcement, and compliance [Online] Availebale: isar.unctad.org/meetings/en/ Presentation/ ciiisar31_1510AM_NStevenson_en.pdf [Accessed: 10 Febr. 2015].

[31] Tomorrow's Business Success. [Online] Available: integratedreporting.org/wp-content/ uploads/2014/10/Tomorrows-Business-Success_Integrated-Reporting-L-Oct-2014.pdf. [Accessed: 1 May 2015] 
[32] Towards Integrated Reporting - Communicating Value in the $21^{\text {st }}$ Century. [Online] Available: // www. ir.org.ru /attachments/article-IR Discussion Paper-2011.pdf. [Accessed: 1 February 2014]

[33] Welcome to the IR Yearbook 2014. [Online] Available: http://integratedreporting.org/yearbook2014/ timeline assets/timeline.html\#vars!date=2011-09-22_10:06:30! [Accessed: 17 Aug. 2015].

[34] World Congress of Accountants 2014 [Online] Available: //www.accaglobal.com/ng/en/member/ accounting business/insights/ congress-2014.html [Accessed: 28 March 2015].

[35] Zamberlan, C. O., Zamberlan, J. F. Systems of costs in agribusiness: a Study in the area of the Fourth Italian Colony. Custos e Agronegocio. 2009, Vol. 5, p. 2-14. ISSN 1808-2882. 